\title{
Hubungan antara guru dan orang tua melalui program parenting perkembangan anak
}

\author{
Fitriati Badiah Purnamasari \\ Universitas Ibn Khaldun Bogor, Indonesia \\ fitriati.purnamasari27@gmail.com
}

\begin{abstract}
Abstrak
Tujuan dari penelitian ini adalah mengetahui hubungan antara guru dan orangtua melalui parenting perkembangan anak di Paud Sahabat Bintang dengan menggunakan metode grounded research dengan responden sebanyak 10 orang yang terdiri dari 3 orang guru dan 7 orang tua murid di sekolah dan teknik observasi dan wawancara. Berdasarkan hasil analisis dapat disimpulkan bahwa perlunya keseimbangan antara pengasuhan di sekolah dan rumah serta mengawasi anak bergaul dengan temannya
\end{abstract}

Kata kunci: parenting; perkembangan anak; pendekatan sosial

\section{Pendahuluan}

Heru Kurniawan dan Risdianto Hermawan (2016) mengemukakan program parenting yaitu kegiatan yang dilakukan antara orang tua dan pihak sekolah dalam membahas proses tumbuh kembang anak dan berbagi permasalahannya agar terjadi kesinambungan dalam rangka optimalisasi potensi anak.

Dalam pengembangan karakter Shochib (1998) menemukan bahwa ada beberapa prinsip pengasuhan orang tua yang menentukan apresiasi anak terhadap nilai disiplin diri yang ditanamkan. Prinsip tersebut meliputi keteladanan diri kebersamaan dengan anak dalam merealisasikan nilai moral, sikap demokratis dan terbuka dalam kehidupan keluarga, menghayati kehidupan anak, kesatuan kata dan tindakan. Artinya orang tua memiliki peranan dan tanggung jawab yang besar untuk perkembangan anak mulai dari penanaman nilai moralitas, dan membimbing sebuah keluarga yang harmonis dengan akhlaqul yang karimah.

Pendapat yang dikemukakan Mansur (2011) yang dikembangkan oleh Ismaniar dan Vevi Sunarti pada Buku Ajar Pelatihan Parenting bahwa dibutuhkan pendekatan yang akan digunakan dalam kegiatan pembelajaran yang memusatkan perhatian kepada anak. Keterlibatan dari lingkungan keluarga, sekolah dan masyarakat secara bersama-sama anak mendatangkan hasil yang lebih optimal.

Orang tua mendidik anak tidak bisa hanya berdasarkan insting dan menirukan kebiasaan-kebiasaan dari orangtua mereka. Akan tetapi karena pengetahuan pendidikan dan teknologi yang semakin berevolusi pesat maka peran orang tua anak usia dini sangat penting sebagai pendidikan pertama bagi anaknya. Orang tua mesti mempelajari setiap pengetahuan dan teknologi pada zaman sekarang yang sarat dengan berbagai tantangan. 
Menurut Dri Atmaka (2004) Pendidik adalah orang yang bertanggung jawab untuk memberikan bantuan kepada siswa dalam pengembangan baik fisik dan spiritual. Artinya guru menjadi pemberi ilmu, pendidik, pembimbing, pelatih sekaligus menjadi orangtua kedua di lingkungan sekolah guna mewujudkan pendidikan yang cemerlang di masa yang akan datang. Sedangkan orang tua Menurut Hurlock pada Wikipedia Google merupakan orang dewasa yang membawa anak ke dewasa, terutama dalam masa perkembangan. Tugas orang tua melengkapi dan mempersiapkan anak menuju kepada kedewasaan dengan memberikan bimbingan dan pengarahan yang dapat membantu anak dalam menjalani kehidupan. Dalam ranah pendidikan, keluarga merupakan pendidikan pertama dalam kehidupan serta yang memberikan bimbingan dan pengarahan pada anak akan berbeda pada masing-masing orang tua kerena setiap keluarga memiliki kondisikondisi tertentu yang berbeda corak dan sifatnya antara keluarga yang satu dengan keluarga yang lain.

Soemiarti Patmonodewo yang dikembangkan oleh Siti Mawaddah Huda (2018) menjelaskan bahwa pada kenyataannya tidak mudah menjalin kerjasama kedua belah pihak. Proses pendidikan seperti mendisiplinkan anak, cara berkomunikasi antara anak dan orang dewasa, anak laki-laki dan perempuan, dan budaya seringkali dipandang berbeda antara guru dan orang tua. Jika hal ini terus berkelanjutan, maka kerjasama tidak akan pernah berlangsung.

Dalam sistem kehidupan bermasyarakat yang berbudaya; orang tua dan guru sebenarnya terlibat aktif dan langsung dalam berbagai aktivitas. Walaupun posisi untuk setiap elemen tersebut berbeda-beda tetapi tetap saling mendukung. Keadaan saling mendukung itulah yang menuntut adanya hubungan interaksi antara guru dengan orangtua. Adanya hubungan baik antara guru dan orangtua untuk membangun komunikasi keduanya dalam rangka menyamakan persepsi kedua belah pihak tentang hal yang dibutuhkan dalam pendidikan anak serta memantau perkembangan belajar anak. Terlebih untuk meningkatkan hasil belajar siswa yang maksimal dengan mengulang pembelajaran di rumah bersama orang tua dengan materi yang telah diberikan guru ketika di sekolah.

Lingkup perkembangan sesuai tingkat usia anak yang mesti diketahui ada enam (6) butir diantaranya : a. Spiritual dan Moralitas dengan tujuan mengenalkan agama yang dianut keluarga, sekolah dan masyarakat Indonesia supaya menjadikan anak yang menghormati, menghargai dan toleran terhadap agama orang lain di lingkungannya selain itu anak dapat berperilaku jujur, penolong, sopan dan santun serta menerapkan nilai-nilai positif lainnya; b. Kognitif dengan tujuan anak dapat berfikir logis, simbolik dan dapat belajar memecahkan masalah yang ditemukan pada kehidupan sehari-harinya; c. Bahasa dengan tujuan mampu mengenalkan anak kosakata, memahami bahasa reseptif, dan mengekspresikan kemampuan bahasa; d. Sosial-Emosional dengan tujuan anak memiliki kesadaran diri dalam mengenal perasaan dan keinginan sendiri, memiliki rasa tanggung jawab terhadap diri sendiri dan barang yang digunakannya, dan perilaku prososial yang berhubungan dengan orang lain seperti : guru, orangtua dan teman 
sebaya; e. Fisik-Motorik dengan tujuan mampu melenturkan anggota badan anak serta menjadikan anak hidup mandiri dan mempunyai perilaku tanggung jawab terhadap diri sendiri ; f. Seni dengan tujuan anak dapat berimajinasi dengan gerakan, musik, drama dan beragam seni lainnya. (Permendikbud 137 bab 4 pasal 10)

Kelompok usia anak menurut Permendikbud 146 adalah (a) lahir - 3 bulan; (b) $3-6$ bulan; (c) 6 - 9 bulan; (d) 9 - 12 bulan; (e) 12 - 18 bulan; (f) 18bulan - 2tahun; (g) $2-3$ tahun; (h) 3 - 4 tahun; (i) $4-5$ tahun; (j) 5 - 6 tahun.

Menurut Piaget pada jurnal Pusat Layanan Pendidikan Anak Usia Dini Terpadu membagi tahapan perkembangan kognitif ke dalam 4 periode, yaitu: a. Usia 0-2 tahun, disebut sebagai periode kepandaian sensorimotorik (sensorimotorik). Periode ini terbagi atas 6 tahapan, yaitu: ? Tahap 1. (lahir-1 bulan) penggunaan refleks-refleks ? Tahap 2. (1-4 bulan) reaksi-reaksi sirkuler primer ? Tahap 3. (4-10 bulan) reaksi-reaksi sirkuler sekunder ? Tahap 4. (10-12 bulan) koordinasi skema-skema sekunder ? Tahap 5. (12-18 bulan) reaksi-reaksi sirkuler tersier ? Tahap 6. (18 bulan-2 tahun) permulaan berpikir b. Usia 2-7 tahun, disebut sebagai periode pikiran operasional (praoperasional konkret). c. Usia 7-11 tahun, disebut sebagai periode operasi-operasi berpikir konkret (operasional konkret) d. Usia 11 tahun, sampai dewasa disebut sebagai periode operasi berpikir formal (operasional formal).

Diantara kedua kelompok usia tersebut dilihat dari perkembangan kognitif, afektif dan psikomotorik memiliki kelompok usia yang berbeda guna membina anak dalam mencapai kesiapan belajar ke jenjang lebih tinggi lagi dengan tekad yang matang tanpa adanya paksaan. Selain itu, acuan materi, lama belajar, model, prinsip dan lainnya pun sudah ditentukan dalam permendikbud supaya pembelajaran dapat berjalan dengan efektif dan efisiensi

Paud Sahabat Bintang berada di Jalan Shaleh Iskandar gg. Kukupu rt 04/08 kelurahan Tanah Sareal Kecamatan Bogor Utara Kota Bogor. Paud Sahabat Bintang juga bergabung dengan Himpaudi Bogor mulai dari tahun 2016 - sekarang. Dipimpin langsung oleh Bu Nuriah Rahayu sebagai Kepala Sekolah dan dua guru lainnya yakni Bu Dian dan Bu Sri. Dengan jumlah murid sebanyak 15 orang; 10 orang perempuan dan 5 orang lainnya lakilaki. Dengan fasilitas yang cukup memadai untuk perkembangan anak. Meskipun begitu, Paud Sahabat Bintang belum berani memajukan lembaganya dengan mengikuti aturan yaitu akreditasi. Sehingga sampai sekarang masih belum bertambah jumalh muridnya karena belumnya diketahui keberadaannya oleh orang tua milenial di daerah Kota Bogor.

Tujuan peneliti menulis ini untuk adanya kesadaran Orang Tua Muda akan tahapan perkembangan anak sesuai dengan usia yang tertera di Permendikbud. Selain itu, dapat menyeimbangkan juga pembelajaran yang diberi dari Guru-Guru PAUD untuk diterapkan di rumah supaya materi sampai dengan baik kepada anak usia dini. Karena anak usia dini hanya sebentar berada di sekolah jadi sangat membutuhkan peran Orang tua selain peran guru untuk setiap tahapan perkembangannya. Dan Orang tua juga tidak bisa hanya mengandalkan anak usia dini pintar secara instan dengan bantuan Guru Paud saja. 


\section{Metode Penelitian}

Metode yang digunakan penelitian dalam penyusunan "hubungan antara guru dan orang tua dalam program parenting perkembangan anak di Paud Sahabat Bintang" adalah Metode Grounded Research. Desain riset grounded theory merupakan seperangkat prosedur yang digunakan untuk menyusun sebuah teori yang menjelaskan sebuah proses mengenai sebuah topik substantif (Egan, 2002). grounded theory berbeda dari banyak metode riset kualitatif lainnya adalah bahwa hal itu secara eksplisit muncul. dimana metode grounded theory tidak menguji hipotesis, namun menetapkan untuk menemukan teori yang bagaimana untuk situasi riset seperti itu. Dalam hal ini adalah seperti tindakan riset yang bertujuan untuk memahami situasi riset dan akhirnya untuk menemukan teori implisit dalam data (Strauss dan Corbin, 1990). Prosedur riset kualitatif dengan menggunakan metode grounded theory terdiri dari beberapa tahap yang dilakukan secara simultan. Adapun tahapan tersebut dimulai dengan tahap perumusan masalah sampai terakhir yaitu menyimpulkan atau penulisan laporan riset. Bertujuan untuk mengembangkan konsep sensitivitas pada masalah yang dihadapi, menerangkan realitas yang berkaitan dengan penelusuran teori dari bawah (grounded theory) dan mengembangkan pemahaman akan satu atau lebih dari fenomena yang dihadapi.

Menurut Sugiyono yang telah dikutip oleh Endin Mujahidin pada tahun 2014, Analisis data yang dilakukan pada penelitian ini bersifat induktif berdasarkan fakta-fakta yang ditemukan di lapangan dan kemudian dikontruksikan menjadi hipotesis atau teori. Pendekatan kualitatif juga digunakan untuk mendapatkan data yang mendalam, yaitu suatu data yang mengandung makna. Oleh karena itu dalam penelitian kualitatif tidak menekankan pada generalisasi, tetapi lebih menekankan pada makna.

Menurut Endin Mujahidin pada tahun 2014, Dalam penelitian ini tiga langkah panduan tersebut dilakukan secara bertahap, dimulai dari identifikasi komponenkomponen atau unsur komunikasi pembelajaran yang ada di Paud, apakah sudah sesuai dengan permendikbud 137 dan 146. Kemudian dilanjutkan dengan identifikasi peran masing-masing komponen yang spesifik seperti Kepala Sekolah yang selanjutnya dilakukan analisa sistem komunikasi pembelajaran seperti apakah yang terjadi di Paud Sahabat Bintang.

Penelitian dilakukan di Paud Sahabat Bintang dengan menggunakan metode grounded research dengan responden sebanyak 10 orang yang terdiri dari 3 orang guru dan 7 orang tua murid di sekolah. Menurut Sugiyono yang telah dikutip oleh Endin Mujahidin pada tahun 2014, Data kualitatif yang telah dianalisis akan diinterprestasikan dengan mengembangkan struktur dan hubungan yang bermakna. Proses interprestasi dilakukan dengan mengacu kepada landasan teoritis yang jelas, setelah dimasukkannya data ke dalam konteks.

\section{A. Perkembangan Anak}

\section{Hasil dan Pembahasan}


Menurut Kartini Kartono pada tahun 2007 yang telah disusun ulang oleh Murni pada tahun 2017, Anak dilahirkan di dunia dalam kondisi serba kurang lengkap, sebab semua naluri, fungsi jasmaniah, serta rohaniahnya belum berkembang dengan sempurna. Oleh karena itu anak manusia mempunyai kemungkinan panjang untuk bebas berkembang. Maksud dari Bebas itu sendiri Anak dapat bertahan hidup dan menyesuaikan diri terhadap lingkungannya di kemudian hari. Bahkan Anak dapat meningkatkan taraf kedewasaannya pada usianya yang masih belia atau malah sebaliknya. Itu hanya masalah waktu dan kembali kepada bagaimana cara Lingkungannya yang mendidik.

Di dalam Peraturan Menteri Pendidikan dan Kebudayaan Nomor 146 tahun 2014 tentang Kurikulum 2013 Pendidikan Anak Usia Dini pada pasal 5 dinyatakan bahwa aspek-aspek pengembangan dalam kurikulum PAUD mencakup: nilai agama dan moral, fisik-motorik, kognitif, bahasa, sosial-emosional, dan seni.

Menurut Danuta Bukatko dan Marvin W. Daehler tahun 2004 yang telah dirangkum oleh Masganti Sit tahun 2015 menyatakan perkembangan anak usia dini mencakup perkembangan otak, keterampilan motorik, fisik, persepsi, bahasa, kognitif, inteligensi, emosi, konsep diri, nilai-nilai, dan gender.

Menurut Laura E. Berk tahun 2006 yang telah dirangkum oleh Masganti Sit tahun 2015 menyatakan ruang lingkup perkembangan anak mencakup perkembangan fisik, kognitif, kecerdasan, bahasa, emosi, sosial, dan moral.

Dari pengertian diatas dapat disimpulkan bahwa Perkembangan anak dilihat dari Nilai Agama dan Moral, Kognitif, Bahasa, Sosial - Emosional, Fisik - Motorik, dan juga Seni.

Pada rumusan waktu, usia 2-6 tahun ialah masa keemasannya manusia. Sebagaimana otak yang masih segar dan bersih itu mulai mencontoh dan mempelajari dari hal-hal kecil sekalipun dan dari yang terdekat; berada di sekitarannya. Yang dimana setiap kelompok usia berbeda proses pembelajarannya. Menurut permendikbud 146 dan 137, Indikator Pencapaian Perkembangan anak disusun berdasarkan kelompok usia Anak adalah

\section{1. lahir - 3 bulan}

Hingga memasuki usia 1 bulan, bayi hanya bisa melakukan gerak refleks (gerakan alami diluar kesadaran bayi). Seperti refleks hisap, refleks gengam, refleks leher, rooting reflex.

Pada bayi bulan ke 2 dan ke 3, gerakan refleks mulai menghilang. Hilangnya gerakan refles ini akan di ganti tahap demi tahap munculnya gerak motorik kasar. Bayi bisa menatap,tersenyum,dan bersuara, juga bayi mulai berusaha mengangkat kepala jika bayi tengkurap

\section{3 - 6 bulan}

- Bermain dengan kedua tangan dan memasukannya kedalam mulutnya.

- Tertawa, bergurau

- Tengkurap

- Menggulingkan badan 
- Berusaha meraih dan menyentuh mainan

- Bertopang pada kedua tangan

- Memindahkan mainan dari satu tangan ketangan lain

- Menoleh mencari datangnya suara

3. 6 - 9 bulan

- Bermain dengan tangan dan kaki

- Mulai senang mengoceh

- Belajar duduk

- Membalikan badan

- Memperhatikan gerak - gerik orang lain

- Merangkak dan merayap

- Dapat berdiri tegak bila dipegang

- Bermain Ciluk Ba!

4. 9 - 12 bulan

- Berayun pada tangan dan lutut

- Merangkak dengan cepat

- Belajar berdiri sambil berpegangan

- Menjepit benda dengan kedua jari tangan

- Belajar berjalan kesamping atau merambat dengan berpegangan atau bisa berjalan sendiri

5. 12 - 18 bulan

- Mencuci tangan dengan bantuan

- Merespon larangan orangtua namun masih memerlukan pengawasan dan bantuan

- Memegang gelas dengan dua tangan

- Memasukkan benda-benda ke dalam wadah

- Menumpahkan benda-benda dari wadah

- Menanyakan nama benda yang belum dikenal

- Mengenal beberapa warna dasar (merah, biru, kuning, hijau)

- Menyebut nama sendiri dan orangorang yang dikenal

- Menyebutkan bilangan tanpa menggunakan jari dari 1-10 tetapi masih suka ada yang terlewat

- Merespons pertanyaan dengan jawaban "Ya atau Tidak" 
- Menirukan bunyi, suara, atau musik dengan irama yang teratur

\section{18bulan - 2tahun}

- Susunan tumbuh dan berubah secara cepat

- Timbulnya gerakan reflex

- Penurunan tangisan

- Meningkatnya kemampuan untuk bergerak, dimulai dari menggeliat-geliat, kemudian menggelinding, merayap, merambat cepat, dan kemudian berjalan

- Meningkatnya kemampuan untuk mengkoordinasi motorik halus tangan dan mata

- Meningkatnya kemampuan "bantuan diri"

- Perkembangan motorik kasar

- Merangkak

- Berdiri dan berjalan beberapa langkah

- Berjalan cepat

- Cepat-cepat duduk agar tidak jatuh

- Merangkak di tangga

- Berdiri di kursi tanpa pegangan

- Menarik dan mendorong benda-benda berat

- Melempar

- Perkembangan motorik halus

- Mengambil benda kecil dengan ibu jari atau telunjuk

- Membuka 2-3 halaman buku secara bersamaan

- Menyusun menara dari balok

- Memindahkan air dari gelas ke gelas

- Belajar memakai kaus kaki sendiri

- Menyalakan TV dan bermain remote

- Belajar mengupas pisang

- Mulai mampu berjalan dan mengeksplorasi rumah serta keliling rumah

- Dapat mengatakan 5-10 kata

- Memperlihatkan rasa cemburu dan rasa bersaing

Peranan orang tua

- Menyediakan pilihan yang tepat dalam menyediakan pengalaman-pengalaman indoor maupun outdoor yang dapat membantu anak untuk melatih perkembangan motorik halus dan motorik kasar mereka 
- Tidak menekan anak untuk melebihi batas kemampuan. Bebaskan anak untuk mencoba setiap tahap perkembangan motorik secara menyeluruh

- Berikan perhatian pada setiap keterlambatan perkembangan yang membutuhkan campur tangan profesional

\section{2 - 3 tahun}

- Membawa benda kecil dengan mudah

- Memakai pakaian

- Memungut benda kecil dengan mudah

- Menggunakan ganggan pintu dengan tepat

- Jalan menaiki tangga

- Menendang bola

- Bicara dengan baik dengan mengunakan 2 kata

- Dapat menunjukkan satu atau lebih dari tubuhnya

- Makan nasi sendiri tanpa banyak tumpah

- Melepas pakaian sendiri

- Motorik halus

- $\varnothing$ Memotong dan Menempel

Memotong Kertas

Memotong dengan gunting

Memegang kertas dan gunting dengan dengan benar (menggunting dengan 2 tangan)

- $\varnothing$ Kebutuhan diri sendiri

Makan dengan sendok

Minum dari secangkir gelas

Melepas pakaian dengan hal yang paling mudah

- $\varnothing$ Mengekspresi benda grafis

- Mencorat coret sesuai dengan keinginan

- Membuat garis atau lingkaran

- Berusaha membuat huruf kapital secara sederhana dengan meniru

- Motorik kasar

- Ø Berjalan

○ Dapat berjalan dengan 2 kaki ke atas tangga

- $\varnothing$ Berlari

○ Berlari dengan berbelok - belok dan dapat berhenti dengan cepat

- $\varnothing$ Melompat 
Melompat dan berpijak menggunakan 2 kakinya

- Ø Memanjat

Mampu memanjat ke atas dengan peralatan meskipun tidak dapat turun kebawah

8. 3- 4 tahun

- Meronce benda yang cukup besar

- Menggunting kertas mengikuti pola garis lurus

- Berat badan dan Tinggi badan sesuai Tingkat usia serta Berat badan sesuai dengan standar tinggi badan

- Membersihkan kotoran (ingus)

- Menggosok gigi

- Mengelap tangan dan muka sendiri

- Memahami kalau berjalan di sebelah kiri

- Mengenal beberapa huruf atau abjad tertentu dari A-z yang pernah dilihatnya

- Naik-turun tangga atau tempat yang lebih tinggi dengan kaki bergantian

- Meniru gerakan senam sederhana seperti menirukan gerakan pohon, kelinci melompat)

- Berdiri dengan satu kaki

9. 4 - 5 tahun

- Mengetahui agama yang dianutnya

- Meniru gerakan beribadah dengan urutan yang benar

- Mengucapkan doa sebelum dan/atau sesudah melakukan sesuatu

- Mengenal perilaku baik/sopan dan buruk

- Membiasakan diri berperilaku baik

- Mengucapkan salam dan membalas salam

- Menirukan gerakan binatang, pohon tertiup angin, pesawat terbang, dsb

- Melakukan gerakan menggantung (bergelayut)

- Melakukan gerakan melompat, meloncat, dan berlari secara terkoordinasi

- Melempar sesuatu secara terarah

- Menangkap sesuatu secara tepat

- Melakukan gerakan antisipasi

- Menendang sesuatu secara terarah

- Memanfaatkan alat permainan di luar kelas

- Membuat garis vertikal, horizontal, lengkung kiri/kanan, miring kiri/kanan, dan lingkaran 
- Menjiplak bentuk

- Mengkoordinasikan mata dan tangan untuk melakukan gerakan yang rumit

- Melakukan gerakan manipulatif untuk menghasilkan suatu bentuk dengan menggunakan berbagai media

- Mengekspresikan diri dengan berkarya seni menggunakan berbagai media

- Mengontrol gerakan tangan yang meggunakan otot halus (menjumput, mengelus, mencolek, mengepal, memelintir, memilin, memeras)

- Berat badan sesuai tingkat usia

- Tinggi badan sesuai tingkat usia

- Berat badan sesuai dengan standar tinggi badan

- Lingkar kepala sesuai tingkat usia

- Menggunakan toilet (penggunaan air, membersihkan diri) dengan bantuan minimal

- Memahami berbagai alarm bahaya (kebakaran, banjir, gempa)

- Mengenal rambu lalu lintas yang ada di jalan

- Mengenal benda berdasarkan fungsi (pisau untuk memotong, pensil untuk menulis)

- Menggunakan benda-benda sebagai permainan simbolik (kursi sebagai mobil)

- Mengenal konsep sederhana dalam kehidupan sehari-hari (gerimis, hujan, gelap, terang, temaram, dsb)

- Mengetahui konsep banyak dan sedikit

- Mengkreasikan sesuatu sesuai dengan idenya sendiri yang terkait dengan berbagai pemecahan masalah

- Mengamati benda dan gejala dengan rasa ingin tahu

- Mengenal pola kegiatan dan menyadari pentingnya waktu

- Memahami posisi/kedudukan dalam keluarga, ruang, lingkungan sosial (misal: sebagai peserta didik/anak/teman)

- Mengklasifikasikan benda berdasarkan fungsi, bentuk atau warna atau ukuran

- Mengenal gejala sebab-akibat yang terkait dengan dirinya

- Mengklasifikasikan benda ke dalam kelompok yang sama atau kelompok yang sejenis atau kelompok yang berpasangan dengan 2 variasi

- Mengenal pola (misal, $\mathrm{AB}-\mathrm{AB}$ dan $\mathrm{ABC}-\mathrm{ABC}$ ) dan mengulanginya

- Mengurutkan benda berdasarkan 5 seriasi ukuran atau warna

- Membilang banyak benda satu sampai sepuluh 
- Mengenal konsep bilangan

- Mengenal lambang bilangan

- Mengenal lambang huruf

- Menyimak perkataan orang lain (bahasa ibu atau bahasa lainnya)

- Mengerti dua perintah yang diberikan bersamaan

- Memahami cerita yang dibacakan

- Mengenal perbendaharaan kata mengenai kata sifat (nakal, pelit, baik hati, berani, baik, jelek, dsb)

- Mendengar dan membedakan bunyibunyian dalam Bahasa Indonesia (contoh, bunyi dan ucapan harus sama)

- Mengulang kalimat sederhana

- Bertanya dengan kalimat yang benar

- Menjawab pertanyaan sesuai pertanyaan

- Mengungkapkan perasaan dengan kata sifat (baik, senang, nakal, pelit, baik hati, berani, baik, jelek, dsb)

- Menyebutkan kata-kata yang dikenal

- Mengutarakan pendapat kepada orang lain

- Menyatakan alasan terhadap sesuatu yang diinginkan atau ketidaksetujuan

- Menceritakan kembali cerita/dongeng yang pernah didengar

- Memperkaya perbendaharaan kata

- Berpartisipasi dalam percakapan

- Menunjukkan sikap mandiri dalam memilih kegiatan

- Mengendalikan perasaan

- Menunjukkan rasa percaya diri

- Memahami peraturan dan disiplin

- Memiliki sikap gigih (tidak mudah menyerah)

- Bangga terhadap hasil karya sendiri

- Senang mendengarkan berbagai macam musik atau lagu kesukaannya

- Memainkan alat musik/instrumen/benda yang dapat membentuk irama yang teratur

\section{5 - 6 tahun}

- Melakukan gerakan tubuh secara terkoordinasi untuk melatih kelenturan, keseimbangan, dan kelincahan 
- Melakukan koordinasi gerakan mata-kakitangan-kepala dalam menirukan tarian atau senam

- Melakukan permainan fisik dengan aturan

- Terampil menggunakan tangan kanan dan kiri

- Melakukan kegiatan kebersihan diri

- Menggambar sesuai gagasannya

- Meniru bentuk

- Melakukan eksplorasi dengan berbagai media dan kegiatan

- Menggunakan alat tulis dan alat makan dengan benar

- Menggunting sesuai dengan pola

- Menempel gambar dengan tepat

- Mengekspresikan diri melalui gerakan menggambar secara rinci

- Menunjukkan aktivitas yang bersifat eksploratif dan menyelidik (seperti: apa yang terjadi ketika air ditumpahkan)

- Memecahkan masalah sederhana dalam kehidupan sehari-hari dengan cara yang fleksibel dan diterima sosial

- Menerapkan pengetahuan atau pengalaman dalam konteks yang baru

- Menunjukkan sikap kreatif dalam menyelesaikan masalah (ide, gagasan di luar kebiasaan)

- Mengenal perbedaan berdasarkan ukuran: "lebih dari"; "kurang dari"; dan "paling/ter"

- Menunjukkan inisiatif dalam memilih tema permainan (seperti: "ayo kita bermain pura-pura seperti burung")

- Menyusun perencanaan kegiatan yang akan dilakukan

- Mengenal sebab-akibat tentang lingkungannya (angin bertiup menyebabkan daun bergerak, air dapat menyebabkan sesuatu menjadi basah)

- Mengklasifikasikan benda berdasarkan warna, bentuk, dan ukuran (3 variasi)

- Mengklasifikasikan benda yang lebih banyak ke dalam kelompok yang sama atau kelompok yang sejenis, atau kelompok berpasangan yang lebih dari 2 variasi

- Mengenal pola ABCD-ABCD

- Mengurutkan benda berdasarkan ukuran dari paling kecil ke paling besar atau sebaliknya

- Menyebutkan lambang bilangan 1-10

- Menggunakan lambang bilangan untuk menghitung 
- Mencocokkan bilangan dengan lambang bilangan

- Mengenal berbagai macam lambang huruf vokal dan konsonan

- Merepresentasikan berbagai macam benda dalam bentuk gambar atau tulisan (ada benda pensil yang diikuti tulisan dan gambar pensil)

Dari masing-masing kelompok usia diatas hanya sedikit dari banyaknya pengalaman dan pedoman untuk para calon orang tua muda untuk perkembangan anaknya kelak. Supaya tahu dan mengerti apa saja yang dibutuhkan setiap bayi dan balita yang komunikasinya dengan tangisan atau senyuman saja (karena belum bisa bicara). Selain itu orang tua dapat melakukan penilaian atas setiap perkembangan yang muncul setiap waktunya. Dan dapat menjadikan momen atau waktu yang sangat berkualitas.

\section{B. Konsep Parenting}

Parenting melibatkan mendidik orang tua dalam peran mereka sebagai anak mereka guru pertama. Program ini secara khusus menargetkan cara orang tua dapat merespons secara positif dan bekerja sama terhadap inisiatif interaksi terhadap masalah yang dihadapi Anak.

Menurut Azar \& Rohrbeck tahun 1986 yang telah dirumuskan oleh Mattew, dkk. Tahun 2003, Ini melibatkan penjelajahan dengan orang tua harapan mereka, asumsi dan keyakinan tentang penyebab perilaku anak-anak, dan memilih tujuan yang berkembang sesuai usia anak dan realistis untuk orang tua. Terdapat bukti bahwa orang tua yang beresiko disalahgunakan anak-anak dan lebih cenderung memiliki harapan yang tidak realistis bagi kemampuan anak-anak.

Menurut Mattew, dkk pada tahun 2003 Program ini memungkinkan orang tua untuk menerima dukungan pengasuhan cara yang paling hemat biaya mungkin. Dalam konteks ini sejumlah program berbeda dengan berbagai intensitas telah dikembangkan. Misalnya, menyediakan intervensi untuk faktor risiko keluarga tambahan, seperti konflik hubungan, gangguan mood dan tingkat stres yang tinggi.

Menurut Sanders \& Dadds, 1982; Sanders \& Glynn, 1981 yang telah dirumuskan oleh mattew di tahun 2003, tidak semua orang tua menggeneralisasikan keterampilan mereka ke situasi berisiko tinggi setelah pelatihan keterampilan aktif awal. Situasi berisiko tinggi ini karena kurangnya generalisasi seringkali ditandai dengan tuntutan yang bersaing, kendala waktu atau oleh menempatkan orang tua di bawah tekanan dalam konteks evaluatif sosial. Untuk orang tua ini, penambahan keterampilan manajemen diri seperti perencanaan ke depan, penetapan tujuan, pemantauan diri, pemilihan perubahan perilaku tertentu strategi di muka dan merencanakan kegiatan yang menarik untuk membuat anak-anak sibuk efektif dalam mengajar orang tua menggeneralisasikan keterampilan mereka.

Parenting juga sangat penting dilakukan guna adanya komunikasi perkembangan anak antara orang tua di sekolah dan orang tua di rumah. Supaya adanya keseimbangan dalam membangun perkembangan dan pertumbuhan yang baik dan sesuai dengan pedoman atau acuan yang sudah tertera pada peraturan-peraturan yang ada di 
Indonesia. Selain itu anak pun merasa senang karena adanya pantauan dan perhatian lebih dalam mendukung pertumbuhan dan perkembangannya.

\section{Parenting menurut Pandangan Islam}

Ada beberapa prinsip parenting dalam pandangan Islam

1. Senantiasa mendoakan anak.

Mendoakan ini bisa dimulai saat sang anak belum lahir, dengan meminta kepada Allah keturunan yang shaleh. Dan setelah mereka terlahir di dunia dengan mendoakan mereka hidayah dan kebaikan.

2. Adil di antara anak dan menjauhi sikap zhalim dan tidak adil.

Jika orang tua tida bersikap adil di antara anak mereka, maka akan terdapat rasa permusuhan, hasad, dan kebencian antara mereka

3. Lemah lembut, kasih sayang, dan berbuat baik terhadap anak. Jauhi sifat kasar dan kaku.

Jika lemah lembut ada pada suatu hal pasti dia akan menjadikan hal itu indah. Dan tidaklah hilang dari sesuatu pasti hal itu akan menjadi rusak. Lakukan kelemahlembutan, kasih sayang, dan perhatian terhadap anak sedari mereka kecil.

\section{Orang tua memiliki semangat untuk mengarahkan anak-anaknya kepada} perkara yang mulia.

Hal ini dilakukan dengan cara memberi pengajaran tentang akidah Islamiyah dan kewajiban-kewajiban agama. Kemudian melarang mereka dari yang haram serta memperingatkan mereka dari perbuatan dosa.

5. Memperhatikan teman-teman mereka, terutama teman dekat.

Karena teman dekat yang bertemu secara intens akan mempengaruhi satu sama lain

6. Orang tua harus menjadi teladan bagi anaknya.

Jangan orang tua menjadi seseorang yang memerintahkan anaknya kepada kebaikan, namun dia sendiri tidak melakukannya. Jangan pula melarang mereka dari kejelekan, tapi dia sendiri malah melakukannya.

\section{Kesimpulan}

Pada Pengasuhan Anak untuk menjadikan anak yang shalih/shalihah, penurut dan membanggakan keluarga, bangsa dan negara perlunya keseimbangan antara pengasuhan di sekolah dan rumah serta mengawasi anak bergaul dengan temannya. Maka dari itu, hubungan antara Guru dan Orang tua sangat diperlukan. Sebab apabila hanya mengandalkan guru, anak tidak tumbuh kembang dngan baik karena guru mendidik hanya 3-4 jam saja selama di sekolah sedangkan selebihnya berada di rumah bersama orang tua dan bisa jadikan momen bersama anak atau waktu yang berkualitas untuk sang anak juga.

Perkembangan anak dilihat dari 6 aspek yakni Nilai Agama dan Moral, Kognitif, Bahasa, sosial-Emosional, Fisik-Motorik, dan juga Seni. Tahapan perkembangan anak dibagi menjadi 10 kelompok usia yang dimana pembagiannya pada masa keemasan 
manusia, yakni ; usia 0-6 tahun. Juga terdapat acuan pernilaian perkembangan agar mendapatkan anak yang ideal menurut dunia. Dari masing-masing kelompok usia diatas hanya sedikit dari banyaknya pengalaman dan pedoman untuk para calon orang tua muda untuk perkembangan anaknya kelak. Dan juga pembelajarannya ditiap kelompok usia berbeda di tingkat kesulitannya namun tetap sama-sama untuk mencerdaskan Anak.

\section{Daftar Pustaka}

Mujahidin, E. 2015. Pendidikan Karakter Bangsa Dalam Perspektif Islam (Studi Kritis Terhadap Konsep Pendidikan Karakter Kementerian Pendidikan \& Kebudayaan). Jurnal Pendidikan Islam. Vol. 4, No. 1 diakses Oktober 2019

Desmita. 2009. Psikologi Perkembangan Peserta Didik Bandung : PT. Remaja Rosdakarya (Http://Cahayalaili.Blogspot.Com/2011/05/Hubungan-Guru-Dan-Orangtua-DalamProses.Html) Oktober, 2019

Huda, Siti Mawaddah. 2018. Kerjasama Guru Dan Orang Tua Dalam Meningkatkan Hasil Belajar Siswa. Skripsi. Tidak Diterbitkan. Pendidikan Agama Islam. Fakultas Ilmu Tarbiyah Dan Keguruan. Universitas Islam Negeri Sumatera Utara : Medan

Pusitaningtyas, Anis. 2017. Pengaruh Komunikasi Orang Tua Dan Guru Terhadap Kreativitas Siswa. Universitas Muhammadiyah Sidoarjo diakses Oktober 2019 (Https://Www.Researchgate.Net/Publication/317074801 Pengaruh Komunikasi Orang Tua Dan Guru Terhadap Kreativitas Siswa)

Senowarsito, Dkk. 2012. Parenting Anak Usia Dini. Article Pdf Available diakses Oktober 2019

(Https://Www.Researchgate.Net/Publication/320128008 Parenting Untuk Anak Usia Dini)

Ismaniar, Vevi Sunarti. 2018. Buku Ajar Pelatihan Parenting. Penerbit Jurusan Pendidikan $\begin{array}{lllll}\text { Luar Sekolah } & \text { Fip Unp } & \text { Diakses }\end{array}$ (Https://Www.Researchgate.Net/Publication/326928635 Buku Ajar Pelatihan P arenting)

Permendikbud 146. 2004. Kurikulum 2013 Pendidikan Anak Usia Dini

Permendikbud 137. 2014. standar Nasional Pendidikan Anak Usia Dini

Noni Ganevi. tt. Pelaksanaan Program Parenting Bagi Orangtua Dalam Menumbuhkan Perilaku Keluarga Ramah Anak (Studi Deskriptif Di Pendidikan Anak Usia Dini AlIkhlas Kota Bandung) (File:///C:/Users/User/Downloads/5425-10743-1-Sm.Pdf)

Https://Sinta.Unud.Ac.Id/Uploads/Dokumen Dir/F19e0a0551976baf0eecd497c39612 00.Pdf Rabu, Oktober 2019

Wijana, Wd. Konsep Dasar Pendidikan Anak Usia Dini (Http://Repository.Ut.Ac.Id/4724/1/Paud4409-M1.Pdf) Rabu, Oktober 2019

Kurniawan, Heru, Dkk. 2016. Program Parenting Untuk Membentuk Karakter Anak Usia Dini Di Lembaga Pendidikan Anak Usia Dini. Aș-Ṣibyan. Vol.1. No.1 